David A. Savitz

William M. Marine Lawrence B. Gratt

Bruce 19. Perry

\title{
Apri1 1984
}

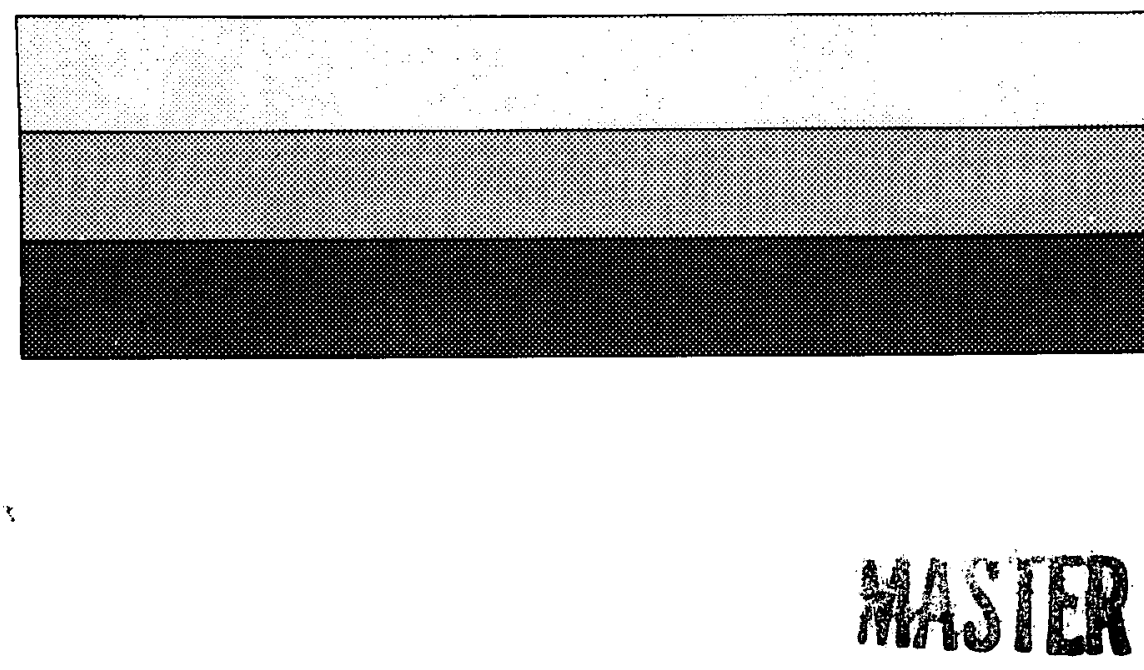

This docment is

PUBLICL" TELEASABLE 


\section{DISCLAIMER}

This report was prepared as an account of work sponsored by an agency of the United States Government. Neither the United States Government nor any agency Thereof, nor any of their employees, makes any warranty, express or implied, or assumes any legal liability or responsibility for the accuracy, completeness, or usefulness of any information, apparatus, product, or process disclosed, or represents that its use would not infringe privately owned rights. Reference herein to any specific commercial product, process, or service by trade name, trademark, manufacturer, or otherwise does not necessarily constitute or imply its endorsement, recommendation, or favoring by the United States Government or any agency thereof. The views and opinions of authors expressed herein do not necessarily state or reflect those of the United States Government or any agency thereof. 


\section{DISCLAIMER}

Portions of this document may be illegible in electronic image products. Images are produced from the best available original document. 


\section{NOTICE}

Work performed under the auspices of the U.S. Department of Energy by the Lawrence Livermore Laboratory under contract number W-7405-ENG-48.

This document was prepared as an account of work sponsored by an agency of the United States Government. Neither the United States Government nor any agency thereof, nor any of their employees, makes any warranty, expressed or implied, or assumes any legal liability or responsibility for the accuracy, completeness, or usefulness of any information, apparatus, product, or process disclosed, or represents that its use would not infringe privately owned rights. Reference herein to any specific commercial product, process, or service by trade name, trademark, manufacturer, or otherwise, does not necessarily constitute or imply its endorsement, recommendation, or favoring by the United States Government or any agency thereof. The views and opinions of authors expressed herein do not necessarily state or reflect those of the United States Government or any agency thereof. 
HYDROCARBON-INDUCED CANCER RISKS IN OIL SHALE PROCESSIKG*

\author{
David A. Savitz and William M. Marine \\ Univeraity of Colorado \\ Health Sciences Center \\ Campus Box C-245 \\ 4200 Best Ninth Avenue \\ Denver, C0 80262
}

\author{
Lawrence B. Gratt and Bruce W. Perry \\ IWG Corp. \\ 975 Hornblend Street \\ Suite C \\ San Diego, CA 92109
}

\section{ABSTRACT}

An estimate of occupational cancer risks due to hydrocarbon exposure during retorting, upgrading, and transportation was ierived using epidemiological studies in a surrogate industry. The oil refining industry was selected as a surrogate with the goal of adjusting that workforce's risk based upon toxicologic and exposure data. Risk estimates were derived for those cancers which may be excessive in refinery worker $B$, namely lung, stomach, kidney, brain, and skin cancer. The ms snitude of health risks for these diseases was very sinall, with the estimated 15,000 exposed workers ouffering 3.7 excess internal cancers per year and 21 excess skin cancers per year. This morbidity would be expected to produce about 3 deaths per year. In spite of considerable uncertainty regarding these figures, the conclusion that hydrocarbon-induced cancers are overshadowed by dust-related respiratory disease as an occupational health risk in the oil shale industry is warranted. The implications of these results for further health research and industrial hygiene practices are discussed.

\section{INTRODUCTION}

The objective of the 1982 oil shale risk analysis was to entinate the potential human health and environmental risks of an oil shale industry in order to establish important research needed to reduce the uncertainties in the estimated risks. The results are reported and disseminated in the Health and Environmental Effects Document (HEED) for oil Shale (1) and were summarized in the 16 th oil Shale Symposium ( $\underline{2})$. The information contained herein is not intended for and should not be used for regulatory purposes. The methodology developed to evaluate hydrocarbon-induced occupational cancer risks will be presented. The relationship to other occupational health risks will be considered, along with the implication of these results for further bealth research and industrial hygiene practices.
This paper will consider the hydrocarbon-induced cancer risks for the occupational workforce for a one million barrels-per-day steady-state production scenario using the probabilistic risk formulation developed for this analysis (2). The cancer risk has been formulated as the product of four factors: the health effect or damage function times the exposure modifier times the biologic (toxicologic) modifier times the population at risk. Oncertainty in the risk estimate is also an important part of the analy8is. The results are expressed in terms of the magnitude of the risk estimate, $R$, and the uncertainty factor, $\left(\nabla_{R}\right)$, used to generate the uncertainty range. The risks and uncertainties generated incorporate both objective and subjective considerations. The resulting range on the risk estimate is computed by $R / U_{R}$ to $R \cdot U_{R}$.

\section{BACKGR OUND}

Cancer in oil shale workers has been a concern since the first reported health effect of excess scrotal cancer ( 3 ). In 1923, Alexander Scott, in sumarizing over twenty-four years of continuous practice as Medical Examiner for the industry $(4,5)$, estimated the incidence of epitbeliomas to be approximately $0.1 \%$ per year. This rate is due to the uncontrolled exposure conditions. Scott reported, for example, that the Green shed workers "are daily for long periods in contact with unrefined oily paraffin, the bare forearms being exposed and the clothing getting wet with drops and splashes of oil."

In about the same period, the British textile industry experienced hundreds of deaths from "Mule Spinner's Cancer." This scrotal cancer was attributed to worker exposure to crudely refined mineral oils, much of which is known to have been of shale origin. While lubricating the spindles or "mules", the worker's clothing became saturated with the oils, and the prolonged intense contact proved carcinogenic. The incidence of this disease decreased after 
the 1950's as different lubricants were used, special regulations took place, and better hygiene practices became routine ( $\underline{6})$.

The oil shale industry in the northwestern region of Estonia S.S.R. is currently the largest commercial oil shale operation in the world. The Institute of Experimental and Clinical Medicine of the Ministry of Health of the Estonian S.S.R. has conducted a variety of industrial hygiene and epidemiological studies on the local populations. In a historical prospective study of 2069 oil shale workers, Purde and Rahu (ㄱ) compared stomach, okin, lung, and uterine cancer incidence rates with general population rates in Estonia. An excess of skin cancer cases occurred only in women who had worked for 10 to 20 years in the industry.

While the Onited States oil shale experience has not reached a commercial level, some pilot operations have involved enough workers to begin to investigate occupational cancers. The first U.S. occupational health study was conducted by the U.S. Public Health Service at Anvil Points Oil Shale Demonatration Plant in 1952 (8). A high incidence of benign skin lesions was noted, although no cancers were found. Recently, NIOSH conducted another study at Anvil Points to determine the health effects, if any, of occupational exposure to shale oil (g) . The investigation included a mortality atudy of 713 men who worked at Anvil Point s during 1948-1969, and a morbidity study of 325 workers from the same pool a the mortality study. The number of deathe by cause were compared to the number expected standardized for age, sex, and race. Results are reported as the ratio of observed to expected deaths, defined as the standardized mortality ratio (SWR). The mortality study found significant increases in SWR for malignant neoplasms, particularily respiratory and colon cancers, and significant decreases in SMRs for diseases of the circulatory system and heart disease. Reduced heart disease mortality is generally found in cohorts of industrial workers. The lung and colon cancer increase may be due to smoking or radon exposure and not necessarily exposure to oil shale materials. The Los Alamos Scientific Laboratory has conducted an occupational health study of the Anvil Points facility a vell for the Department of Energy and the American Petroleum Institute. According to their findings, none of the observed effects could be attributed to exposure to oil shale operations (10).
A battery of in-vitro and in-vivo tests has been performed on oil shale and its products to evaluate their biologic potency. Much of the experimental research has focused upon mutagenicity in short-term in-vitro screening tests and carcinogenicity in animal skin bioassays.

The results of the Ames Salmonella assay system tests show that crude and certain fractionated (basic and neutral fractions) shale oils are mutagenic (11, 12). These studies also indicate significant cytotoxic effects of the shale oil fuels. Experiments utilizing mammalian cell systems, with and without exogenous metabolic activation, were performed and positive results were observed.

Shale oils have been assumed to be carcinogenic because of their similarities with known carcinogens, such as coal tar, and because of human experiences in the early textile industry (Mule-Spinner's Cancer). It is generally thought that the carcinogenicity exhibited in these materials is caused by the polycyclic aromatic hydrocarbon content, auch as benzo(a) pyrene (13). However, upon fractionation, it was found that shale oil mutagenicity is determined primarily by the polycyclic aromatic primary amineo within the alkaline fraction, opecifically ara-arenes and aromatic primary amines $(14,15,16)$. The mutagenicity of petroleum crudes is, however, determined almost solely by the neutral constituents, specifically the polycyclic aromatic hydrocarbons. Thus, the amine content in shale oil may be responsible for the greater observed biological activity of shale oil relative to petroleum (17).

\section{METHODOLOGY}

The potential cancer hazard from exposure to hydrocarbons is one of a number of potential occupational health hazards involved in the extraction, retorting, upgrading, transporting, and refining of shale oil. Human health risks are best estimated from epidemiologic data with the support of in-vivo and in-vitro test results. The hydrocarbon cancer analysis was based on a surrogate approach where data from industries of similar or analogous exposures and practices were extrapolated to the estimated oil shale exposure and the resulting risk was modified according to other relevant knowledge.

The cancer risks vere analyzed using the oimplified equation:

$R=\mathbf{B} \times \mathbf{B} \times \mathbf{T} \times \mathbf{P}$ 
$2 R$ the estimated number of illnesses and $H$ is the excess rate of a health effect in a similar "surrogate" industry. The excess (or attributable) rate is the rate of the disease above the background or baseline level. This rate is derived from the relative risk estimates resulting from epidemiological otudies and the baseline incidence rate of the disease in the general population. The total rate for workers in the surrogate industry is found by multiplying the baseline rate by the relative risk and the excess rate is found by subtracting the baseline rate from the total. $B$ is the ratio of the exposure in the oil shale industry to the exposure in the surrogate industry. T is the biologic or toxicologic modifier which adjusts the risk result to account for the relative biologic potency of oil shale exposure as compared with the surrogate exposure, based upon in-vivo toxicologic tests. $P$ is the estimated size of the exposed worker population.

The selection of the appropriate surrogate industry for estimating the risk of hydrocarbon induced occupational cancers was a critical step of the analysis. The oil refining industry was chosen as the optimal surrogate for oil shale retorting for the following reasons. First, the materials (petroleum and shale oil) are similar in the sense that both are liquid hydrocarbons. Second, both are handled with closed systems where the primary mechanism of exposure is through leaks, accidents, or in maintenance procedures. Third, the products are potentially toxic through both inhalation and direct skin contact. Finally, the involvement of essentially the same corporations in both oil refining and oil shale development suggests that industrial hygiene approaches will be similar. The primary alternative to oil refineries as the surrogate industry is coke production. The value of coke oven workers as a surrogate population is due to the thorough epidemiologic research performed ( $\underline{18}$ ). This population was not used as a surrogate because of the absence of any accurate exposure data for retorting operations. Without having exposure data for scaling the risks, it is impractical to compare retort workers directly to coke oven workers or to any particular subgroup of coke oven workers who best represent retort workers. For the purpose of selecting risks directly from a surrogate industry, oil refining was thought to be more comparable to shale retorting, counterbalancing the admittedly inferior epidemiologic data.
Once the appropriate surrogate was selected, the excess rate of the hydrocarbon-induced cancers vas estimated. Nine epidemiologic studies of oil industry employees were available (19-27). While there was some overlap among the study cohorts, all of the studies were considered as independent risk estimates. The results for each of the examined cancer sites were tabulated, and those sites for which three or more studies suggested positive results were considered in detail. Note that these studies did not need to have found atistically significant risks to qualify, nor did negative finding $s$ in other studies rule out selection of a particular cancer site. Hore stringent criteria would have produced no sites for analysis. The sites which were analyzed are lung, stomach, kidney, brain, and skin cancers. The following approach was used to estimate low, average, and high relative risk estimates. The lower bound of observed risk estimates was established on conceptual grounds as 1.0 (the absence of any adverse occupational effect). All relative risk estimates below 1.0 were considered to be 1.0 , since a protective effect of workplace exposures is not plausible. The high relative risk was an upper bound chosen as the highest observed relative risk estimate. An average risk estimate was then calculated a the arithmetic mean of all the reported risk estimates for refinery workers. The H-term in the methodology is in the form of an excess risk above background attributable to the occupational exposure. Data from the National Cancer Institute $(\underline{28}, \underline{29})$ were used to estimate a baseline cancer incidence rate. This baseline rate multiplied by the relative risk in refinery workers provides an estimated rate in the refinery workers. Subtracting the baseline rate results in the estimate of the occupationally attributable risks, i.e., the excess incidence in those workers. The uncertainty factor for 1 was derived based on the upper bound divided by the average.

In reviewing this analysis, a Committee of the National Research Council (30) recommended a more thorough consideration of study quality in deriving summary risk measures rather than computation of unweighted means. A sensitivity analysis will be conducted to evaluate the impact of different methode of determining research quality. One method was outlined by Dimman and Susman ( 31 ) and provides a useful basis for a quantitative assessment of quality 
The risk formulation includes two terms to modify the risk estimate according to information on exposure and toxicity differences between the surrogate and the oil shale industry. There was a paucity of data on the exposure in both refineries and shale retort operations, and a lack of data to quantify known differences. In both cases, a complex hydrocarbon mixture, having an equally complex polycyclic aromatic hydrocarbon component, is present in the workplace setting at varying concentrations for varying periods of time. Based on a lack of data and expected similarities in industrial hygiene practices, the exposure ratio estimated was to be unity, that is En1. Although the aggregate exposure was estimated to be the same in both settings, the uncertainty about this estimate could be a factor of 25 due to the scarcity of data to derive this estimate.

The toxicologic modifier scales the risk estimate according to differences in the biological potency of the materials to which the workers are exposed. This requires comparative toxicity data between petroleum and shale oils, including many raw and intermediate products and process stream materials. For the analysis, no such comparative data were available for inhalation exposures, although skin painting test data indicate that crude shale oil is more carcinogenic than most crude oils (17). This does not, however, address the actual exposures as each material was treated and refined. For every process stream in the oil shale process, there is a process stream of oimilar toxicity in the refinery surrogate, but the actual duration and intensity of human exposures to those fractions is unquantified in either induatry at the present time. Based on the limited ratios available, a default estimate of 1.0 was used with an uncertainty range of 9 since oil shale substances exhibit from $1 / 3$ to 3 times the biologic potency of petroleum.

Recent toxicologicsl results, such as Union Oil's Premanufacture Notice for Shale Oil Products (submitted to the Environmental Protection Agency under requirement $s$ of the Toxic Substances Control Act) and the American Petroleum Institutés efforts to summarize the chemical, phyoical, and biological properties of materials related to alternate fuels, can be used in future analyses. Although primarily performed for screening purposes, a relative potency approsch may be useful for incorporation of in-vitro results into the risk analysis. The in-vivo results can serve to update the toxicologic term of the risk formulation.

These risk estimates spply to workers in the retort and upgrading facility. This group will be heterogeneous, but application of the H-term derived here as an average for the refinery group appears to be a reasonable estimate for the average of retort and upgrade workers.

The major uncertainties in deriving the hydrocarbon health risk estimates fall into two distinct categories: (1) risk calculations in the petroleum industry and (2) extrapolation of those risks to oil shale retort workers. The major problems in estimating risks among refinery workers are poor characterization of exposure and imprecision regarding latency of carcinogenic effect. The virtual absence of quantitative exposure data precludes any dose-effect estimation other than crude, approximate categorizations. This lack of detail probably dilutes the observed risks since the cohorts studied would include a fairly large proportion of unexposed workers, Similarly, inadequate consideration of latency would tend to mask any existing excess risk ( $\underline{32})$.

Extrapolation of these estimates to oil shale retort workers is another major source of uncertainty. The model includes $E$ and $T$ terms to adjust directly for the different level of exposure and carcinogenicity, but the inability to obtain precise measurement $s$ of either constitutes a significant unknown. An ideal E term would include a person- and time-weighted exposure estimate for both refining and retorting in the form of a total hydrocarbon or polycyclic aromatic hydrocarbon exposure. Similarly, the T-term ideally represents a person- and timeweighted indicator of the carcinogenicity of the measured hydrocarbons. The discrepancy between these ideals and the limitations of the proposed methodo1ogy using available data should be noted.

\section{CANCER RISR ESTIMATES}

The above procedures resulted in an estimate of the terms H (excess risk in the surrogate industry), $E$ (exposure modifier), and $T$ (toxicologic modifier). Since $E$ and $T$ were set at 1.0 , the estimated number of new cases per year was calculated as a function of the excess incidence and the population at risk. It was estimated that 15,000 workers would be involved 
- in the retorting, upgrading, and refining of shale oil and exposed to the associated hydrocarbons.

Table $\hat{l}$ presents the excess incidence estimated in the refinery workforce and the calculated number of new cases expected annually in the oil shale retorting and refining workforce. Non-melanoma skin cancers, which are generally not life-threatening, predominate with over 20 cases per year. Among the more fatal cancers, lung ( 1.73 cases/year) and brain (1.04 crses/year) head the list. Nonetheless, the overall magnitude of all these cancers is small compared to the baseline incidence.

Table 1. Cancer Incidence Rates and Cares

\begin{tabular}{llcc}
\hline $\begin{array}{l}\text { Cancer } \\
\text { Site }\end{array}$ & $\begin{array}{c}\text { Excess } \\
\text { Incidence } \\
\text { per 1000 } \\
\text { per Year } \\
\text { (B-term) }\end{array}$ & $\begin{array}{c}\text { Number of } \\
\text { Worker } \\
\text { at Risk } \\
\text { (x1000) } \\
(\text { P-term) }\end{array}$ & $\begin{array}{c}\text { New Cases } \\
\text { per Year } \\
\text { (R-term) }\end{array}$ \\
\hline Lung & 0.115 & 15 & 1.73 \\
Stomach & 0.039 & 15 & 0.59 \\
$\begin{array}{l}\text { Kidney } \\
\text { Brain }\end{array}$ & 0.022 & 15 & 0.33 \\
Skin & 0.069 & 15 & 1.04 \\
$\begin{array}{l}\text { Melanoms } \\
\text { Basal }\end{array}$ & 0.029 & 15 & 0.44 \\
Squamous & 1.080 & 15 & 16.20 \\
\hline
\end{tabular}

The methodology was designed to identify areas of major uncertainty. Table 2 presents uncertainty factors for each of the components in the risk estimation. The lack of knowledge regarding exposure conditions in the oil shale industry is the predominant factor, with significant uncertainty also due to

Table 2. Uncertainty of Cancer Risk Components and Risk Estimates

\begin{tabular}{|c|c|c|c|c|c|c|c|}
\hline \multirow{2}{*}{$\begin{array}{c}\text { Cancer } \\
\text { Site }\end{array}$} & \multicolumn{3}{|c|}{ Uncertainty } & \multicolumn{2}{|c|}{ Factor } & \multirow{2}{*}{$\begin{array}{c}\text { Best } \\
\text { Eotimate } \\
\text { (cases } \\
\text { per year) }\end{array}$} & \multirow[t]{2}{*}{ Range } \\
\hline & $\mathrm{U}_{\mathbf{H}}$ & $\mathrm{U}_{\mathrm{E}}$ & $\mathrm{U}_{\mathrm{T}}$ & $\mathrm{U}_{\mathrm{P}}$ & $\mathbf{U}_{\mathbf{R}}$ & & \\
\hline $\begin{array}{l}\text { Lung } \\
\text { Stomach } \\
\text { Ridney } \\
\text { Brain }\end{array}$ & $\begin{array}{l}3.16 \\
3.16 \\
3.16 \\
3.16\end{array}$ & $\begin{array}{l}5 \\
5 \\
5 \\
5\end{array}$ & $\begin{array}{l}3 \\
3 \\
3 \\
3\end{array}$ & $\begin{array}{l}1.5 \\
1.5 \\
1.5 \\
1.5\end{array}$ & $\begin{array}{l}10 \\
10 \\
10 \\
10\end{array}$ & $\begin{array}{l}1.73 \\
0.59 \\
0.33 \\
1.04\end{array}$ & $\begin{array}{l}0.17-17.3 \\
0.06-5.9 \\
0.03-3.3 \\
0.10-10.4\end{array}$ \\
\hline $\begin{array}{l}\text { Mel amona } \\
\text { Ba sa I } \\
\text { Squamous }\end{array}$ & $\begin{array}{l}3.16 \\
5 \\
5\end{array}$ & $\begin{array}{l}5 \\
5 \\
5\end{array}$ & $\begin{array}{l}3 \\
3 \\
3\end{array}$ & $\begin{array}{l}1.5 \\
1.5 \\
1.5\end{array}$ & $\begin{array}{r}9.96 \\
12.93 \\
12.93\end{array}$ & $\begin{array}{r}0.44 \\
16.20 \\
4.35\end{array}$ & $\begin{array}{l}0.04-4.4 \\
1.25-210 . \\
0.33-57 .\end{array}$ \\
\hline
\end{tabular}

$\log U_{R}=\sqrt{\left(\log U_{H}\right)^{2}+\left(\log U_{B}\right)^{2}+\left(\log U_{T}\right)^{2}+\left(\log U_{P}\right)^{2}}$ the oil refinery health risks and the toxicologic characteristics of hydrocarbon exposures in both the oil shale and oil refining industries.

Fatality rates were derived to examine the differences in disease severity among cancers and across other disease entities (bronchitis, etc.). Fatality rates were based upon 5 year survival statistics reported from the National Cancer Institute (33). This fatality analysis, presented in Table 3, revealed a different ranking of the threat posed by different types of cancer, with lung, brain, and stomach overshadowing the others. Nonetheless, the total estimated excess cancer mortality was only 3.49 cases per year in the 15,000 person workforce.

Table 3. Hydrocarbon-Induced Cancer Risk

\begin{tabular}{lccc}
\hline $\begin{array}{l}\text { Cancer } \\
\text { Site }\end{array}$ & $\begin{array}{c}\text { Case Fatality } \\
\text { Rate }(\boldsymbol{X})[1]\end{array}$ & $\begin{array}{c}\text { Best Ratimate } \\
\text { (fatality/year) }\end{array}$ & Range \\
\hline Lung & 91 & 1.57 & $0.16-16.0$ \\
Stomach & 88 & 0.52 & $0.052-5.2$ \\
Ridney & 56 & 0.18 & $0.018-1.8$ \\
Brain & 82 & 0.85 & $0.085-8.5$ \\
Skin & 38 & 0.17 & $0.017-1.7$ \\
$\quad$ Melanoma & 38 & 0.16 & $0.012-2.1$ \\
$\quad$ Basal & 1 & 0.04 & $0.003-0.52$ \\
$\quad$ Squamous & 1 & &
\end{tabular}

[1] Derived from Hyers and Bankey (33).

\section{CONCLUS IONS}

Two conclusions can be drawn from this analyais of cancer in the oil shale workforce. First and foremost, there is substantial uncertainty due to potential inaccuracy in health risk estimates for refinery workers, a pacity of data on exposure levels, and a lack of toxicologic data which can be linked to worker exposures. Second, in spite of the se uncertainties, the analysis suggests that cancer hazards are not substantial, at least in comparison to dust-induced disease (34). In fact, risks of the predicted magnitude would be difficult if not imposaible to detect using standard epidemiologic techniques. The upper bound estimates are less reassuring but also less probable than the "best estimates" which were presented.

Research needs are apparent based upon this analysis. First, the accuracy of risk estimates among refinery workers needs to be improved. This is an area of active research and new literature will be incorporated into future analyses as it is published. 
Second, realistic exposure estimates are needed for the oil shale industry employees. Systematic industrial hygiene surveys are essential to establish more accurate risk estimates and prioritize needed control technology. While toxicology studies have thoroughly evaluated kerogen and related products, a more direct link to the exposures would increase the value of such research. Comparative toxicology of oil shale exposures to coke oven emissions, for example, would allow for the development of risk estimates based upon the extensive epidemiologic data on coke oven workers. This analysis has provided an estimate of future risks and, by consideration of areas of uncertainty, provided suggestions for research priorities.

\section{ACKNOWLEDGEMENTS}

This analysis was performed under sponsorship of the U.S. Department of Energy (DOE) Contract DE-AC02-82ER60087 and Lawrence Livermore National Laboratory (LLNL), Subcontract 4554105 by IWG Corp. and the University of Colorado. Dr. Paul Cho of DOE's Health and Enviromental Risk Analysis Program, office of Energy Research was the project officer and Dr. David Layton was the LLNL project officer.

\section{REFER ENCES}

1. Gratt, L.B., W.R. Chappel1, B.W. Perry, W.M. Marine, D.A. Savitz, and J.L. Peerer, Health and Environmental Effects Document for 0il Shale 1982. IWG Corp., IWG-FR-003-01, San Diego, California, December 31,1982 .

2. Gratt, L.B., "Oil shale health and environmental risk analysis." In: Gary, J.H., ed., Sixteenth 0il Shale Symposium Proceedings, Pp. 541-549, Colorado School of Mines Press, Colorado, August 1983.

3. Bell, J., "Paraffin epithelioma of the scrotum." Edinburg Med, J, 22: 135, 1876.

4. Scott, A., "On occupation cancer of the paraffin and oil workers of the Scottish shale oil industry." Brit. Med. J. 2: 1108-1109, 1922.

5. Scott, A., "The occupational dermatoses of the paraffin workers of the Scottish shale oil industry, with a description of the system adopted and the results obtained at the periodic examinations of these workmen." extracted from the Eighth Scientific Report of the Imperial Cancer Research Fund, 1923.

6. Weaver, N.R. and R.L. Gibson, "The U.S. oil shale industry: a health perspective." Am. Ind. Hyg. Assoc, J, 40: 460-467, 1979.
7. Purde, M. and M. Rahu, "Cancer patterns in the oil shale area of Estonian SSR." Environ. Health Perspect. 30: 209-210, 1979.

8. Birmingham, D.J., Interim Report on the 0 il Shale Industry: O.S. Public Health Service (unpublished), Cincinnati, Ohio, 1955.

9. Costello, J., "Morbidity and mortality study of shale oil workers in the United States." Environ. Health Perspect. 30: 205-208, 1979.

10. Rudnick, J., L.L. Garcia, G.L. Voe1z, and H.F. Shulte, Paraho 0il Shale Worker 8 Occupational Health Study. Los Alamos Scientific Laboratory, LA-8459-MS, Informal Report, July 1980.

11. Epler, J.L., B.R. Clark, C.H. Ho, M.R. Guerin, and T.K. Rao, "Short-term bioassay of complex organic mixtures: Part II, Mutagenicity testing." Application of Short-Term Bioassar in the Fractionation and Analysis of Complex Environmental Mixtures. EPA Publ . 600/9-78-027, PP. 269-289, 1978 .

12. Pelroy, R.A. and M.R. Peterson, "Mutagenicity of shale oil component s." Application of Short-Term Bioassay in the Fractionation and Anglysis of Complex Environmental Mixtures. EPA Publ. 600/9-78-027, PP. 463-475, 1978.

13. Guerin, M.R., "Energy sources of polycyclic aromatic hydrocarbons." In: Gelboin, H.V., and P.0.P. Tso, eds., Polycyclic Hydrocarbons and Cancer. Vol 1., Academic Press, New York, Pp. $3-42,1978$.

14. Pelroy, R.A. and M.R. Peterson, "Use of Ames test in evaluation of shale oil fractions." Environ. Health Perspect. 30: 191-203, 1979.

15. Guerin, M.R., C.H. Ho, T.R. RaO, B.R. Clark, and J.L. Epler, "Polycylic aromatic primary amines as determinant chemical mutagens in petroleum substitutes." Environ. Res. 23: 42-53, 1980.

16. Rao, T.R., J.L. Epler, M.R. Guerin, and B.R. Clark, "Short-term microbial testing of shale oil materials." In: Griest, W.H., M.R. Guerin, and D.I. Coffin, eds., Health Effects Investigation of 0 il Shale Development. Ann Arbor Science, Ann Arbor, Michigan, PP. 161-172, 1981.

17. Holland, L.M. and J.S. Wilson, "Long-term epidermal carcinogenicity studies of shale oil." In: Holland, L.M., and C.G. Stafford, The LoB Alamos Integrated Oil Shale Health and Environmental Program Status Report. LA-8665-8R, 1981 .

18. Redmond, C.R., H.S. Wieand, H.E. Rockette, R.S. Sas8, and G. Weinberg, Long-term Mortality Experience of Steelvorkers. U.S. Department of Health and Human Services (NIOSK) Pub1. No. 81-1 20. U.S. DHHS, PHS, CDC, NIOSH, Cincinnati, Ohio, 1981 .

19. Hanis, N.M., K.M. Stavraky, and J.L. Fowler, "Cancer mortality in oil refinery worker s." J, Occup. Med. 21: 167-174, 1979. 
20.t Hanis, N.M., T.M. Holmes, L.G. Shallenberger, and R.E. Jones, "Epidemiologic study of refinery and chemical plant worker8." J. Occup, Med. 24: 203-212, 1982 .

21. Rushton, L, and M.R. Alderson, "An epidemiological survey of eight oil refineries in Britain." Brit, J. Indust. Med 38: 225-234, 1981 .

22. Schottenfeld, D., M.E. Warshauer, A.G. Zauber, J.G. Meikle, and B.R. Hart, "A prospective study of morbidity and mortality in petroleum industry employees in the United States - A preliminary report." In: Peto, $R$. and $M$. Schneiderman, eds.. Quantification of Occupational Cancer. Cold Spring Harbor Laboratory, Cold Spring Harbor, New York, Pp. 247-265, 1981 .

23. Taber shaw/Cooper Associates, A Mortality Study of Petroleum Refinery Worker 8. Project 0H-1, Prepared for the American Petroleum Institute, September 15, 1974.

24. Theriault, G. and L. Goulet, "A mortality study of oil refinery worker s." J. Occup. Med. 21: $367-370,1979$.

25. Thomas, T.L., P. Decoufle, and R. Moure-Eraso, "Wortality among workers employed in petroleum refining and petrochemical plants." J. Occup. Med 22: 97-103, 1980.

26. Thomas, T.L., R.J. Waxweiler, R. Moure-Eraso, S. Italya, and J.F. Fraumeni, Jr., "Mortality patterns among workers in three Texas oil refineries." J. Occup. Med. 24: 135-141, 1982.

27. Wen, C.P., S.P. Tsai, N.S. Weiss, W.A. McClellan, and R.L. Gibson, "A population-based cohort study of brain tumor mortality among oil refinery workers with a discussion of methodological issues of SMR and PMR." In: Petro, R. and $M$. Schneiderman, eds., Quantification of Occupational Cancer. Cold Spring Harbor Laboratory, Cold Spring Harbor, New York, pp. 413-432, 1981 .

28. Young, J.L., Jr., C.L. Percy, and A.J. Asire, Surveillance, Epidemiology, and End Result : Incidence and Mortality Data, 1973-77. NCI Monograph No. 57. DHHS Pub1. No. (NIH) 81-2330, U.S. GPO, Washington, D.C., 1981 .

29. Scotto, J. and J.F. Fraumeni, Jr., "Skin other than melanoma." In: Schottenfeld, D. and J.F. Fraumeni, Jr., eds., Cancer Epidemiology and Prevention. W.B. Saunders Co., Philadelphia, Pennoylvania, 1982.

30. National Research Council, A Review of the 1982 Department of Energy Bealth and Enviromental Effect 8 As ses sment 8 on Cool Liquefaction and $0 i 1$ Shale Technologies. Comittee on Health and Ecological Effects of Synfuels Industries, National Academy Pres8, Washington, D.C., 1983.

31. Dinman, B.D. and N.B. Sussman, "Uncertainty, risk, and the role of epidemiology in public policy development." J. Occup. Med. 25: 51-516, July 1983 .
32. Rothman, R.J., "Induction and latent periods." Am. J. Epidemiol. 114: 253-259, 1981.

33. Myers, M.H. and B.P. Hankey, "Cancer patient survival in the United States." In: Schottenfeld, D. and JiP. Fraumeni, Jr., eds., Cancer Epidemiology and Prevention. W.B. Sanders Co., Philadelphia, Pennoylvania, 1982.

34. Marine, W.M., D.A. Savitz, L.B. Gratt, and B.W. Perry, "Risk of dust-induced lung disease in oil shale worker 8." In: Gary, J.H., ed., Seventeenth 0il Shale Symposium Proceedinge, Colorado School of Kines Press, Golden, Colorado, 1984. 